\title{
Review regarding the genomic evolution in sheep milk production and their application to improve the selection criteria
}

\author{
Cristina Lazăr*, Mihail Alexandru Gras, Rodica Stefania Pelmus, Cătălin Mircea Rotar, Florin Popa \\ National Research Development Institute for Animal Biology and Nutrition (INCDBNA) Laboratory of Management of Animal Genetic \\ Resources, Calea București no. 1, Balotești, Ilfov, 077015, România
}

\section{A B S T R A C T}

\begin{abstract}
Genomic era beginning in 2009 when a lot of studies were undertaken in small ruminants to revel the animal genomes and this new technology make possible this achievement with specific tools like ovine SNP chip. First countries with tradition in sheep production that participated and implemented this new technology for Genomic evaluation were Australia, New Zealand followed by France that applied genomics in dairy sheep and goats. Researches were made recently to fill the existent gap for sheep dairy breeds having in mind the examples from dairy cattle from United States of America. The complex mechanism of milk production involves many genes responsible with different tasks. Some of this genes had the expression in the mammary gland. Genomics helps a lot sheep breeders by minimizing genotyping cost with a better understanding of how to maximize benefits of genomic selection. To be able to accomplish worldwide foods necessities for human requirements, we must have in mind the demographic explosion, the climate change and the eminent crises that will appear soon, in agriculture and animal science and start to found sustainable solutions for these problems. Genomic information helps a lot to take the most appropriate decision when is all about how to select an animal that must be genetically conserved, avoiding the biased estimating breeding values and keeping the genetic diversity.
\end{abstract}

Keywords: Genomics; Sheep breeds; Estimated genomic breeding value; Genomic evaluation; Genomic selection

\section{INTRODUCTION}

Genetic variability of Sheep global population account approximately 1300 breeds very well adapted in a variety of different climates as a result of genetic selection for milk, meat and wool production, (Scherf, 2000). Sheep were chosen to participate on human consumption for being so fitted to the demands of the third world countries to cover the basic necessity for food and clothe with meat, milk, and wool fiber and also because of the suitable requirements for housing and breeding conditions, having a short generation interval and a docile behavior, (Alkass at al., 2017; Ulises, 2020). Even so in time the human necessity for meat and wool decreased in the last 4 decades and the preferences were directed to the beef, pork and chicken and that why the sheep population declined in the last 15 years for the countries with tradition like Australia, New Zealand, USA, France, England, Spain (FAOSTAT, February, 2013). The opportunity that remained this days for sheep industry was for the niche products requirements of the American consumers for organic lamb meat of high quality, cheese specialties and traditional textile as blankets, rugs and clothes. Having in mind these demands researching area was preparing to understand and find out a better possibility to improve and increase constantly the quality of sheep genome. While the productivity was increasing appeared the sensibility of the new sheep breeds to the parasites and the research tendency was to improve this chapter of the genetic markers for internal parasite resistance (Marshall et al., 2011; Matika et al., 2011; Silva et al., 2012). Sheep breeds were also a suitable model for lab experiments and biomedical research with low requirements for housing and having a docile behavior in order to obtain precious information about similar physiological functions for humans, like embryology development, fetal development, immunology, endocrinology, and reproduction. Sheep anatomy and physiology was fitted to explore a few human

\footnotetext{
*Corresponding author:

Cristina Lazăr, National Research Development Institute for Animal Biology and Nutrition (INCDBNA) Laboratory of Management of Animal Genetic Resources, Calea București no. 1, Balotești, Ilfov, 077015, România. E-mail: cristina_lazar17@yahoo.com
} 
disease and to solve health problems like chronic renal failure, Bernstine, (1970), fetal renal disease, Springer et al., (2012), the life span of red blood cells (Carter et al., 1965) and recently disease of human osteoarthritis, Cake et al., (2012), ligament regeneration, (Kon et al., 2012). Sheep genome was first developed starting with information about gene map and research for the identification of gene markers location on each chromosomes using in situ hybridization, Di Meo et al., (2007) and somatic cell hybrid panels, Burkin et al., (1997). Next step to follow in sheep genome was the linkage discovered behind genes maping starting in 1994 with 19 linkage groups with 52 markers and candidate genes RFLP, (Crawford et al. 1994). Booroola fecundity gene was mapped by sheep genome scanning, (Montgomery et al., 1993). International Mapping Flock (IMF) by AgResearch, from New Zealand was starting his activity and the number of loci on the ovine linkage map have increased exponentially using a three-generation pedigree with nine full sibs families descended from one male by embryo transfer finely reaching to the 246 markers, (Crawford et al., 1995). Then in 2001 Maddox et al., (2001) continued the research and ovine linkage map developed reaching at 1093 loci and in 2012 the number of loci discovered had doubled at 2528, (Jill Maddox, personal communication). A great contribution had the research area in defining the main resources and molecular information to describe entire sheep genome that was used in sheep genetic studies. These studies help a lot to develop genomic resources for sheep and made available important molecular information with the participation of the International Sheep Genomics Consortium (ISGC), composed by scientists from Australia, Canada, China, France, New Zealand, UK, and USA. Even the studies of the genomic information were not so comprehensive like in mice, cattle and human today research work must be continued to expose more about sheep genome. That why the purpose of this review is to underline the main objectives that must be reached by the sheep breeding farmers for dairy sheep production that are using the most modern methodology to obtain the genomic breeding value. Entire world is changing with globalization and especially Europe is participating actively by decreasing the production subsidies, and increasing the proportion of health, food safety, animal welfare, and environment conditions traits. That why selection for sheep dairy receive several new important traits to be improved and adopted as new criteria for genomic selection: the ability for milking and udder morphology, diseases resistance to mastitis, internal parasites and scrapie. Genomic evaluation made easier the task of sheep breeders coming with new objectives for selection. Having in mind the human demands regarding milk composition, breeders must pay attention to fat acids composition and bioactive peptides that must be accomplished by fulfilling the nutritional value. Regarding the safety of milk an important aspect is the presence of pathogens or contaminants such as antibiotics or hormones that must be controlled and not be detected in the sheep milk. Another target of the sheep breeders are traits that increase the sheep adaptability to local breeding conditions regarding fitness, wool, longevity and feed efficiency that improve constantly feed intake, body reserves and body weight. A healthy animal has also a great ability for reproduction with important traits that must be improved by genomic selection which are sexual precocity, fertility, prolificacy, out-of-season lambing ability and meat quality by lamb suckling ability.

The classic breeding programs that are for the moment ongoing in dairy sheep in the world until now were based on traditional quantitative approach how lid to an important genetic gains for milk production. Standard methods were used for improving genetic gain and productivity in dairy sheep starting with B.L.U.P. Methodology (Best Linear Unbiased Prediction) which evolved in time from Sire model, (Everett at al., 1984) to Animal model, Mrode, (2005) then appeared Test day model, Bauer at al., (2012) followed by Random regression model, (Schaffer, 2016; Shaffer, 2018). Now this days the classical genetic sources that participated to obtain genetic progress were completed by Marker Assisted Selection, (Barillet, 2007; Miztal at al., 2010) and today the most upgraded selection program is based on Genomic evaluation, (Legarra at al., 2014). Sheep milk production was gradually improved and dairy sheep selection was based recently on milk composition, udder morphology, and Somatic Cell Count that had been implemented with success. Master Assisted Selection helped a lot for scrapie resistance using molecular information. In the beginning the opportunity to embrace other important traits for sheep milk genetic progress was limited by higher costs and was necessary to manager better traditional selection programs closely related with the new approach of the molecular information. Harder work research was enterprise to improve traditional dairy traits beside traits that were costly to record in dairy sheep. That why the most effective strategy was to find out new polymorphic genes affecting sheep dairy traits with economic importance. Genomic approach came naturally having a reach background of the experimental populations created for QTL detection with high-density SNP arrays. Genome-wide selection implies higher costs and is not affordable for the most dairy sheep breeds that why it was difficult to find well-structured reference populations for the estimation of SNP effects for all kind of traits.

\section{Advantages of the genomic selection application for sheep milk production}

Multiple studies were undertaken in small ruminants to revel the animal Genome beginning with 2009 and the 
technologies that make possible this achievement was the development of the $50 \mathrm{~K}$ ovine SNP chip. The countries with tradition in sheep production that participated and implemented this new technology for Genomic evaluation were Australia, New Zealand with a significant sheep population on global level, followed by France that applied genomics in dairy sheep and goats. This opportunity with Genomic evaluation was exploited in United Kingdom, by the sheep breeders that had the intuition to see the advantages offered by its applications. This way sheep breeders could solve specific issues of genomic selection that include: small reference population size, low linkage disequilibrium, multi-breed evaluations, lack of phenotype recording in many countries, and marginal cost-benefit at historic genotyping costs. Genomic helps a lot sheep breeders by minimizing genotyping cost with a better understanding of how to maximize benefits of genomic selection. Worldwide to accomplish the foods necessities for human requirements, having in mind the demographic explosion, the climate change and the eminent crises that will appear soon, in agriculture and animal science we must found sustainable solutions to these problems. Some of these problems will be solved with the help of the sheep and goat breeders that will select the animals specialized for dairy, meat, and wool production.

All this goals will be realized with animal genetic improvement, also for functional traits like reproduction and disease resistance. New method of investigation was discovered beginning with 2007 with the next generation sequencing (NGS) that rapidly made it possible to discover the sequencing in sheep and goats genomes, (Jiang et al., 2014, Dong et al., 2013). With the help of advanced technologies from industry of informatics appeared the opportunity to develop high-density SNP chips of $54 \mathrm{~K}$ used in microarray by the International Sheep Genomics Consortium (ISGC; www.sheephapmap.org; Kijas et al., 2009). Tosser-Klopp et al., (2014) mentioned in his research that in the next year the example of sheep was followed by the International Goat Genome Consortium (IGGC; www. goatgenome.org) and $52 \mathrm{~K}$ chip for goats was developed by Illumina (SNP50 BeadChip; www.illumina.com).

\section{Genomic evaluation in large commercial breeds} represent a challenge from economic point of view that helps the farmers and breeders to improve small ruminants using adequate breeding programs to the requirements of animals and humans. Farther research and investigations are needed to take place for small ruminants alongside with pedigree data, phenotype and genotype that are important to come with genomic data. This was proved already in dairy cows in very efficient way by reducing the interval generation for sires with their selection for dairy traits offered by the daughters. By testing the young bulls the interval generation is smaller and their genome can be seen immediately with reflection in farmer profit. Dairy cows example could be followed by genomic selection in sheep and goats area to improve quickly the genetic progress of the most important traits measured later in the life of reproductive females. All females must be selected for a better longevity of the productive life, better reproduction, motherhood qualities, breeding seasonality, diseases resistance and very good milk production and milk quality composition, (Leggara et al., 2014). The achievement of this desire is stopped by the higher price of the genotyping the animals in the case of sheep and goats breeding. Multiple studies come to show that for the moment is hard to assimilate this modern technology and many of the important traits are measures earlier in the productive life, like growth traits, carcass ultrasound measurements with immediate results for genetic improvement. Genomic selection in sheep and goats were recently applied in countries with tradition in sheep milk production with important number of animal populations like United Kingdom, New Zealand and France, (Mucha et al., 2015; Auvray et al., 2014; Carillier et al., 2013, 2014). Once known the genomic type of the reference population, this become a strong link and an etalon for the related genetic populations with genotyping information linked with the phenotypic performances. Having in mind the limited possibilities of the majority of small ruminant breeder to create a reference population, a few countries had the opportunity to study and create them for pure sheep and goat breeds. The size of this genomic data base is comprehensive for a relative small number of individuals from Western Pyrenees with 1900 animals for dairy sheep breed, (Legarra et al., 2014); followed by United Kingdom with 2400 sheep and France with 2700 goats. Almost a double number was recorded for Lacaune dairy sheep, with 4800 animals (Larroque et al., 2014). In New Zealand, Romney had a pure breed reference population with 5300 individuals. Despite small reference populations, genomic best linear unbiased prediction (GBLUP) resulted in a greater accuracies of EBV (estimating breeding value) than pedigree-based BLUP although for some traits and population, the increase in accuracy was small. Gains in GEBV accuracies were estimated to be by Baloche et al. (2014) between 0.10 and 0.20 across milk production traits in Lacaune dairy sheep. The gain in GEBV accuracy in the French and UK dairy goat populations amounted to 0.06 for milk yield and 0.14 for fat and protein content, (Carillier et al., 2014). The extent of Linkage Disequilibrium estimated by average $\mathrm{r}^{2}$ values between adjacent markers (50kb) ranged from 0.10 to 0.18 for Saanen and Alpine goat populations (Carillier et al., 2013; Brito et al., 2015; Mucha et al., 2015) and were mostly between 0.08 and 0.12 in sheep, (Baloche et al., 2014; Kijas et al., 2014). Soay sheep (Kijas et al., (2014) and boar goat, (Brito et al., 2015) were 
an exception with higher Linkage Disequilibrium (LD) $\left(0.28<\mathrm{r}^{2}<0.30\right)$, which is probably due to low primary effective population size. The LD results indicate that, for some breeds, the addition of new genotypes is mandatory and that a denser SNP panel than the current 50K Beadchip could be beneficial. Also, genomic evaluation methods can substantially improve the accuracies of GEBV estimation when applied to small ruminants and therefore accelerate response to selection. The real gain of the genomic breeding value is that it skips the bias in the estimation making early the selection of the young candidates, and having a better accuracy. The calculation method implies to have a small reference population and is necessary to use a single-step methodology which summarize the phenotype, genotype and relatives relationship data to calculate genomic breeding value, (Leggara et al., 2009); Misztal et al., 2009). An important advantage of this method is that the phenotypic information coming from all animals and their relatives could be analyzed in the same time with the other sources, with or without genotype, having a prediction accuracy between 22-37\% said Carillier et al., (2014) in his study made on Alpine and Saanen breeds. Legarra et al., (2014) has found out that by the usual methodology used until now with relatives information for genetic evaluation and using single-step method made on milk production traits, was discovered in a small reference population of Western Pyrenees, that the last one had a better accuracy with $5 \%$ to $30 \%$. Small population size characterized a multitude of sheep and goat breeds and researchers made multi breed genomic evaluation, mixing different breeds with common selection objectives. They observed that all breeds analyzed together had a very good prediction just in case of using one breed at the time concluded Auvray et al., (2014) in his study for Coopworth, Romney and Perendale with the exception for some traits in Perendale. Further researching was done and three models were applied and compared in goats by Carillier et al., (2014) who found out that the best regression were obtained by the perbreed model beside, multi- trait and multi-breed models. Multiple studies shows that the accuracy of the genomic prediction was lower in case of the large multi-breed and crossbreed sheep populations. That why was needed to use a SNP with a larger sequence than $50 \mathrm{~K}$ that had given a better accuracy by using multi-breed genomic evaluation model, Baloche et al., 2014, Carillier et al. 2014). In his research Legarra et al., (2014) found out that in case of the cosmopolite sheep breeds this may work using multi-breed genomic to mix several of them with common genetic relationship from different countries, with similar traits like Saanen goats and crossbreds from England, France, Canada, and Italy or Boer goats from France. Genetic gain obtained using genomic comparing with traditional way of breeding for sheep grow up with almost $18 \%$ in a reference population with 2000 animals, (Shumbusho et al., 2013). Modern technologies are used to improve the genetic gain by simulation with genotyped selection rams knowing that higher cost were determinate in the past for genotyping. Many studies were concentrate their attention on the Major Genes in sheep and goat which were determinate and associated with different production and reproduction traits important for the breeders. This type of genes have connection with a Mastitis is a disease that affect the milk production in sheep and goats and is determinate by Socs 2 gene, (Rupp et al., 2015). For goats milk production was discovered alfa-S1 casein, which gives a higher quantity of cheese, improving milk capacity of manufacturing, (Leroux et al., 1990). This genes were recently discovered and applications of them were implemented in the breeding program of small ruminants in France for preselection of the progeny testing. The modern technology was used to found this gene markers with a higher price initially, but the cost of sequencing and genotyping this days was reduced and helped a lot to multiply the genomic studies that are coming soon with new discoveries with more major genes.

\section{Genes associated with sheep milk traits}

Multiple qualities recommended sheep milk in the human consume with very healthy products like yogurt, cheese, cheddar having in his composition essential proteins, fats, lactose, and minerals with benefits for human consumption. This natural product obtained from sheep had to meet this qualities by improving constantly milk production traits: milk yield, milk protein, milk fat, and casein and lactose percentages. To achieve this objective very important factors participate and have control on sheep production by different genes that had a different response in each environmental factors. This way the genetic potential could be expressed at the optimal level and improved with each generation. New technologies appeared and come with molecular research to discover by PCR-RFLP genes that influence milk production in Turkish sheep breed, (Ozmen et al., 2014). POU1F1, is a complex protein that encodes a $P O U$ domain protein essential to the terminal differentiation and expansion of somatotrophs, lactotrophs, and thyrotrophs. This protein plays multiple roles being a transcription factor that regulates the transcription of itself and of other hormones and their receptors, growth hormone $(G H)$, prolactin (PRL), Thyroid stimulating hormone beta subunit (TSH $\beta$ ), Thyroid stimulating hormone receptor (TSHR), and growth hormone releasing hormone receptor (GHRHR). Mutations of POU1F1 gene were discovered and are responsible for diseases which give metabolic deficiencies of the GH, PRL, and TSH, (Yin Pang and Yee Chan, 2010). Both authors mention in their research that exist recessive and dominant inheritance of this autosomal genes and heterozygous individuals have a more severe disease symptoms. This mutations are 
discovered in the POU-specific and POU-homeodomains with high-affinity for DNA binding on GH and PRL genes, (Yin Pang and Yee Chan, 2010). The same result obtain also Moioli et al., (2013) in his study and remind his applicability in marker assisted selection. Researchers from wide world extended their studies and observed that these genes have in their componence palmdelphin $(P A L M D)$ and ring finger protein 145 (RFP145) discovered in Italian Altamurana sheep, and alpha-lactalbumin $(L A L B A)$ observed in Spanish Churra sheep, (Moioli et al., 2013, Garsia-Gamez et al., 2012). Both authors mention that PALMID plays its role in cellular mechanism, producing a cytosolic protein implicated in membrane dynamics and RFP145 gene is responsible in cellular metabolism. The growth hormone encoded by the $G H$ gene is involved in growth process and also in milk traits production. That way studies are continuing to appear with new discoveries and do Rosario et al., (2006) observed that GH1 was a gene correlated with lower milk yield in Serrada Estrela breed. Recently, (Dettory et al., 2015) showed that variants of this gene are involved also in tissue expression. Genes associated with milk traits, from sheep genome, are summarized in the table below with details about sheep breeds, chromosome, position on chromosome and their functions accomplished (Table 1).

A lot of studies were undertaken recently to fill the existent gap for sheep dairy breeds having in mind the examples from dairy cattle. The complex mechanism of milk production involves many genes responsible with different tasks. Some of this genes had the expression in the mammary gland and also play an important role in milk transcriptome. A few of them were studied by Georgios et al., (2019) in Chios breed (DNAJA1, GHR, LYPLAL1, NUP35, OXCT1 and RRP15) who found that are implicated in milk yield, each of them with a specific role. $D N A J$ is a proteins family that is involved in the ATP hydrolysis activity, protein folding, and protein transportation, prevents proteolytic degradation. DNAJA1 is a component of this family and acts as a co-chaperone to prevent cells against apoptosis in response to cellular stress, (Gotoh et al., 2004). Research on the role played by this type of genes continued with a study on milk transcriptome on Churra and Assaf breeds, with two genes belonging to the same family, DNAJA4 and DNAJB2, as functional candidates for milk yield, (Suarez-Vega et al., 2017). Later on was observed that this genes influenced milk yield by metabolic and mammary apoptosis which were associated negatively with lactation persistency. The last lactation stages were been affected by declining and the shape curve of daily milk yield reflected this on dairy species, (Stefanon et al., 2002). The growth hormone receptor $(G H R)$ is responsible with growing process, and its expression was discovered in the mammary gland and the milk transcriptome, highly expressed in the liver, comparative to the other tissues analyzed for gene expression in sheep atlas (http://biogps.org/sheepatlas). Georgios et al., (2019) recommends further investigation, on Chios breed, to confirm the GHR gene connection with the sheep milk regulatory mechanism. In dairy cattle researches were done to explain the role played by growth hormone receptor (GHR) which was associated with an increased milk yield and a reduced milk somatic cell count (Tiezzi et al., 2015, Raven et al., 2014, Rahmatalla et al., 2011). Identification of unique and shared selection signals were done by comparison between dairy breeds and beef cattle to see the GHR, (Gutierrez-Gil et al., 2015). For example, 3-oxoacid CoA transferase 1 (OXCT1) has been associated favorably with both milk production, (Bionaz et al., 2008) and mastitis resistance, (Zarrin et al., 2014), and has been suggested to regulate mammary gland metabolism and milk synthesis during mastitis infection, (Tiezzi et al., 2015). In his research Georgios et al., (2019), found the expression of OXCT1 in mammary gland and immune tissues, high expression in the kidney cortex with a similar role in sheep milk yield. OXCT1 and NUP35, were detected in tissues related with milk production, were also enriched in immune related tissues, relative to the other tissues analyzed. The most significant SNP markers discovered for milk yield in similar studies on cattle were located in QTLs that overlaps with other QTLs identified in dairy sheep populations, (Raven et al., 2011), Rahmatalla et al., 2011).

Inclusion of the major genes in the breeding programs Over the years major genes were included in SNP chips with valuable genetic data in the process of pre-selection in order to increase the discoveries of other genes in new animal populations. To be more precise genetic information already known helped a lot to make new discoveries by associating the effect of major genes and QTL with important economic traits included in breeding evaluation represented by adequate models that had to avoid bias. Such an example is the study of Martin et al., 2014 with major gene FecL associated with prolificacy of the Lacaune breed. That why he make remarks about the necessity to increase the research in this direction to discover large QTLs and major genes that will help a lot the genomic evaluation of the sheep populations. Also some recommendations are made with regard to the accomplishment of this desiderate to genotype more and more animals using single-step GBLUP methodology, to deal with multi-allelic gene or QTL haplotype, mixing them to found out their correlation and the benefits. Small ruminant milk production had different breeding goals to achieve and one of them was to improve the casein by the genotype of alfa-s1 casein in selected candidates, (Carillier et al., 2015). A new methodology approach known as Gene Content Multiple trait BLUP was discovered by Legarra and Vitezica, (2015) which demonstrate that it increasing 
Table 1: Genes associated with sheep milk traits

\begin{tabular}{|c|c|c|c|c|c|}
\hline Gene & $\mathrm{Cr}$ & Sheep Breed & Position & Function & Author \\
\hline POU1F1 & 1 & Turkish sheep & $154027868-154043592$ & $\begin{array}{l}\text { Regulate transcription for } \mathrm{GH}, \mathrm{PRL} \text {, } \\
\text { and TSH }\end{array}$ & $\begin{array}{l}\text { Ozmen et al., 2014, } \\
\text { Yin Pang and Yee Chan, } 2010\end{array}$ \\
\hline RFP145 & na & Italian Altamurana & na & responsible in cellular metabolism & Moioli et al., 2013 \\
\hline LALBA & 3 & Spanish Chura & $137390403-137392415$ & responsible in cellular metabolism & Garsia-Gamez et al., 2012 \\
\hline GH1 & 11 & Serrada Estrela & $14849149-14850884$ & lower milk yield & $\begin{array}{l}\text { Vacca et al., 2013, do Rosario } \\
\text { et al., } 2006\end{array}$ \\
\hline $\mathrm{GH}$ & 11 & & $14854339-14856064$ & $\begin{array}{l}\text { growth process, milk traits } \\
\text { production, tissue expression }\end{array}$ & Dettory et al., 2015 \\
\hline PALMD & na & Italian Altamurana & na & $\begin{array}{l}\text { cellular mechanism, producing } \\
\text { a cytosolic protein implicated in } \\
\text { membrane dynamics }\end{array}$ & $\begin{array}{l}\text { Moioli et al., 2013, Garsia-Gamez } \\
\text { et al., } 2012\end{array}$ \\
\hline$P R L$ & 16 & & $38969273-39028126$ & & Bowles, D. \\
\hline DNAJA1 & 2 & Chios & $40136610-40147235$ & $\begin{array}{l}\text { milk yield, metabolism and } \\
\text { mammary apoptosis }\end{array}$ & $\begin{array}{l}\text { Giorgios Banos et al. 2019, Gotoh } \\
\text { T. et al., 2004, Stefanon B. } \\
\text { et al., } 2002\end{array}$ \\
\hline DNAJA4 & 18 & Churra and Assaf & 28602532-28618994 & milk yield & Suarez-Vega A. et al., 2017 \\
\hline DNAJB2 & 14 & Churra and Assaf & $16158346-16171780$ & milk yield & Suarez-Vega A. et al., 2017 \\
\hline OXCT1 & 16 & Chios & $34443788-34607167$ & $\begin{array}{l}\text { expressed mammary gland, } \\
\text { immune tissues, kidney cortex, liver }\end{array}$ & Bionaz M. et al., 2008 \\
\hline CSN1S1 & 6 & Churra and Assaf & $94699768-94716493$ & $\begin{array}{l}\text { Increase Casein quantity for cheese } \\
\text { making }\end{array}$ & $\begin{array}{l}\text { Leroux et al., 1990; Bălteanu } \\
\text { et al., 2010; Lazăr et al., } 2010\end{array}$ \\
\hline CSN1S2 & 6 & Churra and Assaf & $94793750-94810274$ & $\begin{array}{l}\text { Increase Casein quantity for cheese } \\
\text { making }\end{array}$ & Suarez et al., 2017 \\
\hline FASN & 11 & Churra and Assaf & $12314481-12333275$ & milk fat metabolism & Suarez et al., 2017 \\
\hline ACSL1 & 26 & Churra and Assaf & $16088646-16154220$ & milk fat metabolism & Suarez et al., 2017 \\
\hline LPIN1 & 3 & Churra and Assaf & $21243542-21371164$ & milk fat metabolism & Suarez et al., 2017 \\
\hline Socs2 & 3 & $\begin{array}{l}\text { Commercial French } \\
\text { dairy }\end{array}$ & $139298423-139303587$ & $\begin{array}{l}\text { Mastitis, suppressor of cytokine } \\
\text { signaling } 2\end{array}$ & $\begin{array}{l}\text { Rupp et al., 2015; Oget } \\
\text { et al., } 2019\end{array}$ \\
\hline GHR & 16 & Chios & $33625221-33923727$ & $\begin{array}{l}\text { increased milk yield, reduced milk } \\
\text { somatic cell, mammary gland }\end{array}$ & Georgios et al., 2019 \\
\hline LYPLAL1 & 12 & Chios & 24731653-24762461 & $\begin{array}{l}\text { detected in tissues related to milk } \\
\text { production }\end{array}$ & Georgios et al., 2019 \\
\hline NUP35 & 2 & Chios & $136717318-136750188$ & $\begin{array}{l}\text { detected in tissues related to milk } \\
\text { production }\end{array}$ & Georgios et al., 2019 \\
\hline$R R P 15$ & 12 & Chios & $23815587-23867013$ & mammary gland & Georgios et al., 2019 \\
\hline
\end{tabular}

the prediction from 1 to $16 \%$ for milk protein content. There are some major genes with pleiotropic effect like socs 2 mutation which gives a high number of somatic cell and also a higher milk yield and that why we have to pay attention to such type of combination when we prepare to trace the goals of the genomic evaluation, (Rupp et al., 2015). Artificial Insemination is dominant procedure when we take in account the goats and sheep flocks with 50\% for goats and $23 \%$ for sheep in France. Ancestor data are very important and often this type of information is missing and the lack of it is supplemented by the natural mattings with multiple-sire rams groups in intensive growing systems. The relatives' information is very important in increasing the accuracy of the genetic gain closely used to the DNA markers which can be detected if are any missing-identification of parents for each candidate tested, procedure used in New Zealand in multiple mating system (Dodds et al., 2005). Over the world there are using sets of parentage SNPs (BeadArray SNP50K) from different researching teams undertaken in many research centers, and after investigations was discovered that only some of this SNPs sets overlaps and not entirely have in common genetic markers. This research centers that participated were from countries with tradition in sheep meat production: ISGC (http://www.sheephapmap. org/), Ag Research in New Zealand (Clarke et al., 2014), Meat Animal Research Center (USMARC) from the the US (Heaton et al., 2014), CSIRO from Australia, (Heaton et al., 2014), and INRA from France, (Tortereau et al., 2015). That why this become on opportunity for the next years to discover and enlarge the number of the common markers which may define the most important economic traits by identifying new common SNPs between the sheep breeds for both type of dairy and meat production, (Heaton et al., 2014). The same path was followed in goats by using Illumina Caprine BeadChip in Sannen and Alpine goats in France, then in England and Italy to increase the number of farmers wanting to embrace this procedure more and more and this way minimizing the cost of genotyping the animals. The technologies recommended to be used 
with low cost for genotyping the small ruminants were multi-species parentage BeadArray and MassARRAY platform (Sequenom) beginning with a fair price of 10 euros for each animal. Another benefit provided by these technologies was that the genotyped progeny that are included in genomic evaluation are very well appreciated by the extensive sheep farms which were using multi-sire mating and DNA parentage. Studies undertaken until now in other species were closed to the real marketing demands (Dodds et al., 2015).

This new modern strategies comes to solve some important problems that exist in the breeding of small ruminant and research center and consortium are participating a lot in giving solutions like International Sheep and Goat Genomics Consortia. A lot of care and attention was offered by the Management of Diversity Genomics which come to improve animal genetics and survey the variability and diversity of the small ruminant breeds. Genomic information comes with more accuracy closely related by the pedigree performances of the sheep and goat breeds which is welcome in some situation when is not complete or is missing (Eynard et al., 2015). Genomic information helps a lot to be taken the most appropriate decision when is all about how to choose which animal must be genetically conserved, avoiding the biased estimating breeding values and keeping the genetic diversity. With important results and implications in animal improvement (genebank) had developed all over the world great significance for in vivo and in vitro genetic conservation, (Mucha and Windig, 2009). That why these way by sequencing animals must be avoided accidental inbreeding, and specific and rare genetic variants could be identified when in pedigree and on SNP chips can be exposed only most common genetic variants. Genomic studies comes to help a lot the improvement of small ruminant and by conservation to preserve the diversity of the local breeds very well adapted to their environment.

Genomic selection came with a great improvement to the accuracy of estimating breeding value earlier in the life of the young animals, by decreasing the interval generation, and with a more attentive selection of the candidate. Great results were obtained in dairy cows using genomic selection attributes closely to the usual genetic evaluation for bulls in order to increase the selection accuracy for traits with varying heritability knowing that until now progeny testing had long interval generation who generates higher costs. Sheep dairy breeders with pyramidal flux very well organized had beneficiated of the most important activities like official milk recording, complementary natural mating followed by the artificial insemination, (Barillet, 1997, 2007; Carta et al., 2009). These priorities were established in order to have a better population with genetic improvement transferred to the commercial population by rams born from artificial insemination, (Barillet, 1997; Carta et al., 2009). First attempt to improve the genetic gain passing from nucleus to the commercial population was done in France in Lacaune breed and it was observed an improvement of 5 to 7 years (Barillet, 1997; Barillet et al., 2001). Almost 40 years ago the breeding programs had to improve milk production by estimating breeding value with a linear model which combine fat and protein milk yield (Barillet et al., 2001). After six years in Lacaune breed genetic improvement went to almost 6 liters milk yield and $100 \mathrm{~g}$ fat per milk yield liter with more than 400 rams with daughters tested for milk in 400 farms, (Barillet et al., 2007). In the last years in sheep and goat selection the tendency was to improve functional traits which affecting milk production, conformation, reproduction, fitness, resistance to mastitis and scrapie disease in order to decrease the expenses with the productive life and to maximize the effect generated by the Genomic selection, (Schaeffer, 2006). Also exist a lot of advantages by implementing the Genomic selection by decreasing the costs, reducing the genetic interval and improving continuously the nucleus of sheep breeds and having a fluent bonds with commercial flocks with a genetic progress in each generation (Schaeffer, 2006). It is very well known that by a good management of the selection, controlling the inbreeding, new interest traits will appear in the sheep dairy breeding program, (Colleau et al., 2009). Now these days the whole-genome was genotyped and sequencing in sheep and goats and this made possible to scan their genome, with low price, to found out with high-density SNPs chip the most important genetic markers. Genetic diversity of the animals today could be explain using markers for the special cases when the performances are hard to measure, had low heritability or are limited by sex, or may be is necessary to sacrifice the animal, (Goddard and Hayes, 2007; Hayes et al., 2009). A multitude of important traits are detected by markers during the curs of genotyping the dairy sheep when we spoke about parentage testing or PrP gene for scrapie resistance disease. Researching field was conducting studies to reveal how QTL had influence for several productive traits like Somatic Cell Counting, Fat Acid content in milk, udder fitness, nematode resistance, (Barillet, 2007; Gutiérrez-Gil et al., 2008; Carta et al., 2009). Genomic implementation had recent roots with the activities that take place in International Sheep Genomic Consortium (ISGC; http://www.sheephapmap.org) with a very good management control in which is participating 20 countries with a powerful instrument like SNP chip of 60K. In France a large population of Lacaune sheep was participating to the development of an important and representative reference population of this breed by accuracy gained with genomic estimating breeding value, (Astruc et al., (2010). Factors that affecting the reference population size were studied by optimization and one of them was the 
density of markers engaged, explained Meuwissen et al., (2001). Also in real sheep population by comparison a few statistical models obtained a lower accuracy then that obtained by optimization with experimental population by Legarra et al., (2008) and in commercial population by de Roos, (2001). Following this studies in Lacaune breed was obtained a better accuracies for prediction of daughter yield deviations weighted by their effective daughter contribution, (Duchemin et al., 2012).

\section{CONCLUSION}

Genomic discovery become one of the most modern approach methodology for the explanation of the most profound and complex mechanism of genes in animal life. Every new information added is very useful by improving the genetic progress obtained by each generation in sheep milk production. Genomics is born recently and had to develop in the same rhythm with informatics giving a lot of data that must be quantified and valued by finding the connection between them. Sheep Genomics implementation had success mostly with a very good management control in which is participating 20 countries in a powerful congregation named International Sheep Genomic Consortium (ISGC; http:/ /www.sheephapmap. org). Implementing the Genomics selection, this days, costs will decrease, reducing the genetic interval and improving continuously the nucleus of sheep breeds. Sheep Genomic data bases will create a fluent bond between commercial flocks and a valuable nucleus sheep breeds improving the genetic progress in each generation.

\section{ACKNOWLEDGEMENT}

This research was supported by funds from the National Research Project ADER 8.1.10 granted by the Romanian Ministry of Agriculture and Rural Development. The publication was supported by funds from the National Research Development Project Projects to finance excellence (PFE-Valorif) - 17/2018-2020 granted by the Romanian Ministry of Research and Innovation.

\section{Authors contributions}

To accomplish the goals of the present review paper, major contributions had Cristina Lazăr to the conception and writing of the present manuscript and also to found the most important discoveries in the field of breeding and genetics with genomics and to design the paper preparation. The prime author Cristina Lazăr was helped by the contribution of the collaborating authors, Rodica Pelmus, Mihail Gras, Cătălin Rotar and Florin Popa, to document about the Major Genes used in the breeding programs, to found the most recent discoveries of gene associate with milk traits, to establish which is the stage of the genomic evaluation in the dairy sheep and what are the current application of this new methodology and obviously to prepare the writing for this review.

\section{REFERENCES}

Alkass, J., D. Aziz and H. Hermiz. 2017. Genetic parameters of growth traits in Awassi sheep. Emir. J. Food Agric. 3: 152-161.

Astruc, J. M., G. Lagriffoul, H. Larroque, A. Legarra, C. Moreno, R. Rupp and F. Barillet. 2010. Use of genomic data in French dairy sheep breeding programs: Results and prospects. In: Proceeding $37^{\text {th }}$ International Committee for Animal Recording (ICAR) Annual Meeting, Riga, Latvia. ICAR, Rome, Italy.

Auvray, B., J. C. McEwan, S. Newman, A. N. Lee and K. G. Dodds. 2014. Genomic prediction of breeding values in the New Zealand sheep industry using a 50K SNP chip. J. Anim. Sci. 92: 4375-4389.

Baloche, G., A. Legarra, G. Sallé, H. Larroque, J. M. Astruc, C. Robert-Granié and F. Barillet. 2014. Assessment of accuracy of genomic prediction for French Lacaune dairy sheep. J. Dairy Sci. 97: 1107-1116.

Bauer, J., M. Milerski, J. Pribyl and J. Vostry. 2012. Estimation of genetic parameters and evaluation of test-day milk production in sheep. Czech J. Anim. Sci. 57: 522-528.

Barillet, F. 1997. Genetics of milk production. In: I. Piper. and A. Ruvinsky (Ed.), The Genetics of Sheep. CAB International, Wallingford, Oxfordshire, UK, p. 539-564.

Barillet, F., C. Marie, M. Jacquin, G. Lagriffoul and J. M. Astruc. 2001. The French Lacaune dairy sheep breed: Use in France and abroad in the last 40 years. Livestock Prod. Sci. 71: 17-29.

Barillet, F. 2007. Genetic improvement for dairy production in sheep and goats. Small Rum. Res. 70: 60-75.

Balteanu, V. A., A. Vlaic, F. D. Pop, T. C. Carsai, C. Pascal, St. Creanga, N. Zaharia, I. Padeanu, O. S. Voia, M. Sauer and I. V. Sauer. 2010. The study of aS1-casein genetic marker polymorphism in Carpathian goat breed. Sci. Paper Anim. 53: 321-325.

Bernstine, R. L. 1970. A chronic renal model for the fetus. Lab. Anim. Care. 20: 949-956.

Bionaz, M. and J. J. Loor. 2008. Gene networks driving bovine milk fat synthesis during the lactation cycle. BMC Genomics. 9: 366.

Bowles, D., A. Carson, P. Isaac. 2014. Genetic distinctiveness of the Herdwick sheep breed and two other locally adapted hill breeds of the UK. PLoS One. 9: e87823.

Brito, L. F., M. Jafarikia, D. A. Grossi, J. W. Kijas, L. R. Porto-Neto, R. V. Ventura, M. Salgorzaei and F. S. Schenkel. 2015. Characterization of linkage disequilibrium, consistency of gametic phase and admixture in Australian and Canadian goats. BMC Genet. 16: 67.

Burkin, D. J., F. Yang, T. Broad, J. Wienberg, D. F. Hill and M. A. Ferguson-Smith. 1997. Use of the Indian muntjac idiogram to align conserved chromosomal segments in sheep and human genomes by chromosomal painting. Genomics. 46: 143-147.

Cake, M. A., R. A. Read, G. Corfield, A. Daniel, D. Burkhardt, M. M. Smith and C. B. Little. 2012. Comparison of gait and pathology outcomes of three meniscal procedures for induction of knee osteoarthritis in sheep. Osteoarthritic Cartilage. 21: 226-236.

Carillier, C., H. Larroque, I. Palhière, V. Clément, R. Rupp and C. Robert-Granié. 2013. A first step toward genomic selection 
in the multi-breed French dairy goat population. J. Dairy Sci. 96: 7294-7305.

Carillier, C., H. Larroque and C. Robert-Granié. 2014. Comparison of joint versus purebred genomic evaluation in the French multibreed dairy goat population. Gen. Sel. Evol. 46: 67.

Carillier-Jacquin, C., H. Larroque and C. Robert-Granié. 2015. Including casein as1 gene effect on genetic and genomic evaluation of French dairy goats. In: Proceeding $66^{\text {th }}$ Annual Meeting of the EAAP, Warsaw, Poland, 31 Augest-4 September.

Carta, A., S. Casu and S. Salaris. 2009. Invited review: Current state of genetic improvement in dairy sheep. J. Dairy Sci. 92: 5814-5833.

Carter, M. W., G. Matrone and G. Metzler. 1965. Estimation of the life span of red blood cells in the growing animal in different nutritional states. J. Gen. Physiol. 49: 57-67.

Evidence of major gene(s) affecting milk traits in the Chios sheep breed. Small Rum. Res. 105: 61-18.

Clarke, S. M., H. M. Henry, K. G. Dodds, T. W. D. Jowett, T. R. Manley, R. M. Anderson and J. C. McEwan. 2014. A high throughput single nucleotide polymorphism multiplex assay for parentage assignment in New Zealand sheep. PLoS One. 9: E93392.

Colleau, J. J., Fritz, S., Guillaume, F., Baur, A., Dupassieux, D., Boscher, M. Y., Journaux, L., Eggen, A. and D. Boichard. 2009. Simulating the potential of genomic selection in dairy cattle breeding. Rencontr. Rech. Rumin. 16: 419.

Crawford, A. M., G. W. Montgomery, C. A. Pierson, T. Brown, K. G. Dodds, S. L. Sunden, H. M. Henry, A. J. Ede, P. A. Swarbrick and T. Berryman. 1994. Sheep linkage mapping: Nineteen linkage groups derived from the analysis of paternal half-sib families. Genetics. 87: 271-277.

Crawford, A. M., K. G. Dodds, A. E. Ede, C. A. Pierson, G. W. Montgomery, G. Garmonsway, A. E. Beattie, K. Davies, J. F. Maddox and S. W. Kappes. 1995. An autosomal genetic linkage map of the sheep genome. Genetics. 140: 703-724.

Dodds, K. G., M. L. Tate and J. A. Sise. 2005. Genetic evaluation using parentage information from genetic markers. J. Anim. Sci. 83: 2271-2279.

Dong, Y., M., Xie, Y., Jiang, N., Xiao, X, Du, W., Zhang, G., Tosser-Klopp, J. Wang, S. Yang, J. Liang, W. Chen, J. Chen, P. Zeng, Y. Hou, C. Bian, S. Pan, Y. Li, X. Liu, W. Wang, B. Servin, B. Sayre, B. Zhu, D. Sweeney, R. Moore, W. Nie, Y. Shen, R. Zhao, G. Zhang, J. Li, T. Faraut, J. Womack, Y. Zhang, J. Kijas, N. Cockett, X. Xu, S. Zhao, J. Wang and W. Wang. 2013. Sequencing and automated whole-genome optical mapping of the genome of a domestic goat (Capra hircus). Nat. Biotechnol. 31: 135-141.

de Roos, A. P. W. 2011. Genomic Selection in Dairy Cattle. PhD Thesis. Wageningen University Wageningen, The Netherlands.

do Rosário Marques, M., I. C. Santos, N. Carolino, C. C. Belo, R. Renaville, A. Cravador. 2006. Effects of genetic polymorphisms at the growth hormone gene on milk yield in Serra da Estrela sheep. J. Dairy Res. 73: 394-405.

Dettori, M. L., M. Pazzola, E. Pira, P. Paschino and G. M. Vacca. 2015. The sheep growth hormone gene polymorphism and its effects on milk traits. J. Dairy Res. 82: 169-176.

Di Meo, G. P., A. Perucatti, S. Floriot, H. Hayes, L. Schibler, R. Rullo, D. Incarnato, L. Ferretti, N. Cockett, E. Cribiu, J. L. Williams, A. Eggen and L. Iannuzzi. 2007. An advanced sheep (Ovis aries, $2 n=54$ ) cytogenetic map and assignment of 88 new autosomal loci by fluorescence in situ hybridization and R-banding. Anim. Genet. 38: 233-240.

Duchemin, S. I., C. Colombani, A. Legarra, G. Baloche, H. Larroque, J. M. Astruc, F. Barillet, C. Robert-Granié and E. Manfredi. 2012.
Genomic selection in the French Lacaune dairy sheep breed. J. Dairy Sci. 95: 2723-2733.

Everett, R. W. and J. F. Keown. 1984. Mixed model sire evaluation with cattle experience and genetic gain. J. Anim. Sci. 59: 529-541.

Eynard, S. E., J. J. Windig, G. Leroy, van R. Binsbergen and M. P. L. Calus. 2015. The effect of rare alleles on estimated genomic relationships from whole genome sequence data. BMC Genet. 16: 24.

Garcia-Gamez, E., B. Gutiérrez-Gil, G. Sahana, J. P. Sánchez, Y. Bayón and J. J. Arranz. 2012. GWA analysis for milk production traits in dairy sheep and genetic support for a QTN influencing milk protein percentage in the LALBA gene. PLoS One. 7: e47782.

Georgios, B., E. L. Clark, S. J. Bush, P. Dutta, G. Bramis, G. Arsenos, D. A. Hume and A. Psifidi. 2019. Genetic and genomic analyses underpin the feasibility of concomitant genetic improvement of milk yield and mastitis resistance in dairy sheep. PLoS One. 14: e0214346.

Goddard, M. E. and B. J. Hayes. 2007. Genomic selection. J. Anim. Breed. Gen. 124: 323-330.

Gotoh, T., K. Terada, S. Oyadomari and M. Mori. 2004. HSP70DNAJ chaperone pair prevents nitric oxide- and CHOP-induced apoptosis by inhibiting translocation of Bax to mitochondria. Cell Death Differ. 11: 390-402.

Gutiérrez-Gil, B., M. F. El-Zarei, L. Alvarez, Y. Bayón, L. de la Fuente, F. San Primitivo and J. J. Arranz. 2008. Quantitative trait loci underlying udder morphology traits in dairy sheep. J. Dairy Sci. 91: 3672-3681.

Gutierrez-Gil, B., J. J. Arranz, P. Wiener. 2015. An interpretive review of selective sweep studies in Bos Taurus cattle populations: Identification of unique and shared selection signals across breeds. Front. Genet. 6: 167.

Heaton, M. P., K. A. Leymaster, T. S. Kalbfleisch, J. W. Kijas, S. M. Clarke, J. McEwan, J. F. Maddox, Basnayake, V., Petrik, D.T., Simpson, B., Smith, T.P., Chitko-McKown, C.G and International Sheep Genomics Consortium. 2014. SNPs for parentage testing and traceability in globally diverse breeds of sheep. PLoS One. 9: E94851.

Hayes, B. J., P. J. Bowman, A. J. Chamberlain and M. E. Goddard. 2009. Invited review: Genomic selection in dairy cattle: Progress and challenges. J. Dairy Sci. 92: 433-443.

Jiang, Y., M. Xie, W., Chen, R., Talbot, J. F., Maddox, T., Faraut, C., Wu, D. M. Muzny, Y. Li, W. Zhang, J. A. Stanton, R. Brauning and W. C. Barris. 2014. The sheep genome illuminates biology of the rumen and lipid metabolism. Science. 344: 1168-1173.

Kijas, J. W., D. Townley, B. P. Dalrymple, M. P. Heaton, J. F. Maddox, A. McGrath, P. Wilson, R. G. Ingersoll, R. McCulloch, S. McWilliam, D. Tang, J. McEwan, N. Cockett, V. H. Oddy, F. W. Nicholas, H. Raadsma and International Sheep Genomics Consortium. 2009. A genome wide survey of SNP variation reveals the genetic structure of sheep breeds. PLoS One. 4: E4668.

Kijas, J. W., L. Porto-Neto, S. Dominik, A. Reverter, R. Bunch, R. McCulloch, B. J. Hayes, R. Brauning, J and McEwan and International Sheep Genomics Consortium. 2014. Linkage disequilibrium over short physical distances measured in sheep using a high-density SNP chip. Anim. Gen. 45: 754-757.

Kon, E., G. Filardo, M. Tschon, M. Fini, G. Giavaresi, L. M. Reggiani, C. Chiari, S. Nehrer, I. Martin, D. M. Salter, L. Ambrosio and M. Marcacci. 2012. Tissue engineering for total meniscal substitution: Animal study in sheep model results at 12 months. Tissue Eng. Part A. 18: 1573-1582.

Larroque, H., F. Barillet, G. Baloche, J. M. Astruc, D. Buisson, 
F. Shumbusho, V. Clément, G. Lagriffoul, I. Palhière and R. Rupp. 2014. Toward genomic breeding programs in French dairy sheep and goats. In: Proceeding $10^{\text {th }}$ World Congress on Genetics Applied to Livestock Production. Available from: http:// www.bit.ly/1OebpGS.

Lazăr, C., R. Pelmuş, D. Marin and E. Ghiţă. 2010. Preliminary investigations on milk proteins polymorphism in Carpathian goats and in F1 Carpathian Saanen hybrids. Arch. Zootech. 13: 45-57.

Legarra, A., C. Robert-Granié, E. Manfredi and J. M. Elsen. 2008. Performance of genomic selection in mice. Genetics. 180: 611-618.

Legarra, A., G. Baloche, F. Barillet, J. M. Astruc, C. Soulas, X. Aguerre, F. Arrese, L. Mintegi, M. Lasarte, F. Maeztu, I. B. de Heredia and E. Ugarte. 2014. Within and across-breed genomic predictions and genomic relationships for Western Pyrenees dairy sheep breeds Latxa, Manech, and basco-Bearnaise. J. Dairy Sci. 97: 3200-3212.

Leroux, C., P. Martin, M. F. Mahé, H. Levéziel and J. C. Mercier. 1990. Restriction fragment length polymorphism identification of goat alpha s1-casein alleles: A potential tool in selection of individuals carrying alleles associated with a high level protein synthesis. Anim. Gen. 21: 341-351.

Maddox, J. F., K. P. Davies, A. M. Crawford, D. J. Hulme, D. Vaiman, E. P. Cribiu, B. A. Freking, K. J. Beh, N. E. Cockett, N. Kang, C. D. Riffkin, R. Drinkwater, S. S. Moore, K. G. Dodds, J. M. Lumsden, T. C. van Stijn, S. H. Phua, D. L. Adelson, H. R. Burkin, J. E. Broom, J. Buitkamp, L. Cambridge, W. T. Cushwa, E. Gerard, S. M. Galloway, B. Harrison, R. J. Hawken, S. Hiendleder, H. M. Henry, J. F. Medrano, K. A. Paterson, L. Schibler, R. T. Stone and B. van Hest. 2001. An enhanced linkage map of the sheep genome comprising more than 1000 loci. Genome Res. 11: 1275-1289.

Marshall, K., J. F. Maddox, S. H. Lee, Y. Zhang, L. Kahn, J. U. Graswer, C. Gondro, S. W. Walkden-Brown and J. H. J. van der Werf. 2011. Genetic mapping of quantitative trait loci for resistance to Haemonchus contortus in sheep. Anim Genet. 40: 262-272.

Martin, P., J. Raoul and L. Bodin. 2014. Effects of the FecL major gene in the Lacaune meat sheep population. Gen. Sel. Evol. 46: 48.

Matika, O., R. Pong-Wong, J. A. Woolliams and S. C. Bishop. 2011. Confirmation of two quantitative trait loci regions for nematode resistance in commercial British terminal sire breeds. Animal. 5: 1149-1156.

Meuwissen, T. H. E., B. J. Hayes and M. E. Goddard. 2001. Prediction of total genetic value using genome-wide dense marker maps. Gen. 157: 1819-1829.

Misztal, I., A. Legarra and I. Aquilar. 2009. Computing procedures for genetic evaluation including phenotypic, full pedigree, and genomic information. J. Dairy Sci. 92: 4648-4655.

Moioli, B., M. C. Scatà, R. Steri, F. Napolitano and G. Catillo. 2013. Signatures of selection identify loci associated with milk yield in sheep. BMC Genet. 14: 76.

Montgomery, G. W., E. A. Lord, J. M. Penrty, K. G. Dodds, T. E. Brroad, et al. 1993. The Booroola fecundity (FecB) gene maps to sheep chromosome 6. Genomics. 22: 148-153.

Mrode, R. A. 2005. Linear models for the Prediction of Animal Breeding Values. $2^{\text {nd }}$ ed. CABI Publishing, Wallingford.

Mucha, S. and J. J. Windig. 2009. Effects of incomplete pedigree on genetic management of the Dutch Landrace goat. J. Anim. Breed. Gen. 126: 250-256.

Mucha, S., R. Mrode, I. MacLaren-Lee, M. Coffey and J. Conington. 2015. Estimation of genomic breeding values for milk yield in UK dairy goats. J. Dairy Sci. 98: 8201-8208.
Ozmen, O., S. Kul and E. O. Unal. 2014. Polymorphism of sheep POU1F1 gene exon 6 and 30UTR region and their association with milk production traits. Iran. J. Vet. Res. 15: 331.

Rahmatalla, S. A., U. Muller, E. M. Strucken, M. Reissmann and G. A. Brockmann. 2011. The F279Y polymorphism of the GHR gene and its relation to milk production and somatic cell score in German Holstein dairy cattle. J. Appl. Gen. 52: 459-465.

Raven, L. A., B. G. Cocks, M. E. Goddard, J. E. Pryce and B. J. Hayes. 2014. Genetic variants in mammary development, prolactin signalling and involution pathways explain considerable variation in bovine milk production and milk composition. Gen. Sel. Evol. 46: 29.

Rupp, R., P. Senin, J. Sarry, C. Allain, C. Tasca, L. Ligat, D. Portes, F. Woloszyn, O. Bouchez, G. Tabouret, M. Lebastard, C. Caubet, G. Foucras and G. Tosser-Klopp. 2015. A point Mutation in suppressor of cytokine signalling 2 (Socs2) increases the susceptibility to inflammation of the mammary gland while associated with higher body weight and size and higher milk production in a sheep model. PLoS Genet. 11: e1005629.

Rupp, R., S. Mucha, H. Larroque, J. McEwan and J. Conington. 2016. Genomic application in sheep and goat breeding. Anim. Front. 6: 39-44.

Silva, M. V., T. S. Sonstegard, O. Hanotte, J. M. Mugambi, J. F. Garcia, S. Nagda, J. P. Gibson, F. A. Iraqi, A. E. McClintock, S. J. Kemp, P. J. Boettcher, M. Malek, C. P. Van Tassell and R. L. Baker. 2012. Identification of quantitative trait loci affecting resistance to gastrointestinal parasites in a double backcross population of Red Maasai and Dorper sheep. Anim. Genet. 43: 63-71.

Schaeffer, L. R. 2006. Strategy for applying genome-wide selection in dairy cattle. J. Anim. Breed. Genet. 123: 218-223.

Schaeffer, L. R. 2016. Random Regression Models. Available from: http://www.animalbiosciences.uoguelph.ca/ Irs/BOOKS/ rrmbook.pdf.

Schaffer, L. R. 2018. Necessary changes to improve animal model. J. Anim. Breed. Genet. 135: 124-113.

Scherf, B. D. 2000. World Watch List for Domestic Animal Diversity. FAO/UNEP, Domestic Animal Diversity Information System. Food and Agriculture Organization, Rome, Italy. Available from: http://www.fao.org/dad-is/index.asp.

Shumbusho, F., J. Raoul, J. M. Astruc, I. Palhiere and J. M. Elsen. 2013. Potential benefits of genomic selection on genetic gain of small ruminant breeding programs. J. Anim. Sci. 91: 3644-3657.

Springer, A., K. Kratochwill, H. Bergmeister, D. Csaicsich, J. Huber, M. Bilban, B. Mayer, I. Mühlberger, G. Amann, E. Horcher and C. Aufricht. 2012. A combined transcriptome and bioinformatics approach to unilateral ureteral obstructive uropathy in the fetal sheep model. J. Urol. 187: 751-756.

Suarez-Vega, A., B. Gutierrez-Gil, C. Klopp, G. Tosser-Klopp and J. J. Arranz. 2017. Variant discovery in the sheep milk transcriptome using RNA sequencing. BMC Genomics. 18: 170.

Stefanon, B., M. Colitti, G. Gabai, C. H Knight and C. J. Wilde. 2002. Mammary apoptosis and lactation persistency in dairy animals. J. Dairy Res. 69: 37-52.

Tiezzi, F., K. L. Parker-Gaddis, J. B. Cole, J. S. Clay and C. A. Maltecca. 2015. Genome-wide association study for clinical mastitis in first parity us holstein cows using single-step approach and genomic matrix re weighting procedure. PLoS One. 10: e0114919.

Tortereau, F., C. Moreno, G. Tosser-Klopp, L. Barbotte, L. Genestout and J. Raoul. 2015. Development of a SNP parentage assignment panel for French sheep breeds. In: Proceeding $66^{\text {th }}$ Annual Meeting of the EAAP, Warsaw, Poland.

Tosser-Klopp, G., P. Bardou, O. Bouchez, C. Cabau, R. Crooijmans, 
Y. Dong, C. Donnadieu-Tonon, A. Eggen, H. C. M. Heuven, S. Jamli, A. J. Jiken, C. Klopp, C. T. Lawley, J. McEwan, P. Martin, C. R. Moreno, P. Mulsant, I. Nabihoudine, E. Pailhoux, I. Palhière, R. Rupp, J. Sarry, B. L. Sayre, A. Tircazes, J. Wang, W. Wang, W. Zhang and International Goat Genome Consortium. 2014. Design and characterization of a 52K SNP chip for goats. PLoS One. 9: E86227.

Ulises, M. C. 2020. Post-lambing maternal effects in hair ewes fed omega- 6 polyunsaturated fatty acids in the late gestation. Emir. J. Food Agric. 32: 7. Available from: https://www.ejfa.me/index. php/journal/article/view/2129.

Vacca, G., M. Dettori, F. Balia, S. Luridiana, M. Mura, V. Carcangiu,
M. Pazzola. 2013. Sequence polymorphisms at the growth hormone $\mathrm{GH} 1 / \mathrm{GH} 2-\mathrm{N}$ and $\mathrm{GH} 2-\mathrm{Z}$ gene copies and their relationship with dairy traits in domestic sheep (Ovis aries). Mol. Biol. Rep. 40: 5285-5294.

Zarrin, M., O. Wellnitz, H. Avan Dorland, J. J. Grossand R. M. Bruckmaier. 2014. Hyperketonemia during lipopolysaccharide-induced mastitis affects systemic and local intramammary metabolism in dairy cows. J. Dairy Sci. 97: 3531-3541.

Yin Pang, A. L. and W. Y. Chan. 2010. Essential Concepts in Molecular Pathology, Associated with Economically Important Production and Reproduction Traits in Sheep (Ovies aries). Animal Genetic Resources Research Group. 